additional sections, as, for example, the one for the Ukraine, which also contains an account of the natural agricultural belts of the country and the major plant species of each, and the Albanian study, which gives an account of the natural vegetation, crop geography and agricultural practices of that country.

The source of the material for the main section of each study is the climatological data from the various meteorological stations of North America The elements of comparison-monthly and yearly temperatures, maximum and minimum temperatures, average monthly, seasonal and yearly precipitation, precipitation-effectivity indices and ratios (Thornthwaite's method), length of frostless periods, and latitudes-are studied for a particular meteorological station and a search is then made among the North American stations for a "similar climatic and latitudinal environment". The North American environment when found is then noted as being climatically analogous to it. Relief maps of the country are presented to show the location of the various meteorological stations, and the names of States and regions of their North American climatic counterparts are given in each case, if such counter. parts exist. Agro-climatic charts give full meteorological data for each observing station within the country studied and the North American climatic parallel of each.

This agro-climatological series by M. Y. Nuttonson, the background for which was developed by experiences gathered in non-emergency plant introductions where careful varietal field trials of introduced plant material were possible, will be welcomed by all plant exploration and introduction organisations, ecologists, agro-climatologists and geographers. Until such time as meteorological recording instruments are developed to give readings more in keeping with the requirements of agro-climatologists and such factors as evapo-transpiration and potential evapo-transpiration $^{2}$ are taken into account in the formulation of more detailed world homoclimes and agro-climatic ana. logues, they will serve as an excellent basis to all plant introduction work. It is to be hoped, however, that an institute similar to the American Institute of Crop Ecology will be set up in Britain to determine world homoclimes and agro-climatic analogues for the British Commonwealth. The Commonwealth Bureau of Pastures and Field Crops would appear to be the obvious centre for this work. Studies dealing with British Commonwealth agro-climatic analogues for the various countries of the world might well be initiated at this information Bureau. It would also serve as a pool for receiving suggestions from agriculturists and meteorologists concerning new types of meteorological instruments that should be evolved (for example, one for measuring water movement from the earth to the atmosphere) to meet the needs of the modern agro-climatologist and agriculturist generally.

Agricultural expansion in the British Commonwealth will most surely require, among other things, the introduction of new plant material into undeveloped or partly developed areas. Many of these areas will gireatly benefit from new pasture plants, new legumes, etc., which might be obtained as a result of plant explorations in countries having similar homoclimes. For example, there is a proposal to send an Australian expedition to homoclimal areas in South America to study the more promising wild and cultivated plants with the view of transferring some to Australia. South America's richness in useful plant species is considered a valuable source for plant introductions for northern semi-tropical portions of Australia. Similarly it is proposed to send an expedition to Indo-China and Siam with the object of seeking and securing types of the banana family for use on the breeding work in the West Indies.

A series of studies such as have been suggested, dealing with British Commonwealth agro-climatic analogues for the various countries of the world, would undoubtedly facilitate plant introduction, adaptation and exploration work, and serve as a useful complement to the studies at present being carried out in the United States. ${ }^{1}$ Nuttonson, M. Y., International Agro-Climatological Series, American

${ }^{2}$ Thornthwaite, C. W., Geog. Rev., 38, 55 (1948).

\section{SOUTH AFRICAN MUSEUMS ASSOCIATION}

\section{ANNUAL GENERAL MEETING}

$\mathrm{T}$ H.E twelfth annual general meeting of the South African Museums Association was held in the Africana Museum (Public Library building), Johannesburg, during March 16-19. The Mayor of Johannesburg, Mr. G. B. Gordon, opened the meeting on a particularly happy note by remarking on the Johannesburg City Council's appreciation of the value of museums and art galleries in the preservation of objects of art, science and history, and stating that education departments in various parts of the Union had already recognized their importance in adult and juvenile education. In the course of his address, Mr. Gordon also referred to his Council's pledge to establish, in collaboration with the University of the Witwatersrand, a museum of science and industry, and to its promise to provide a site for the South African National War Museum (at present housed in two Bellman hangars in a portion of the Zoological Gardens). By 1952, furthermore, he hoped that a new building to house the Africana Museum would be erected. From this, therefore, it would seem that Johannesburg can look forward to cultural develop. ments with optimism.

Following the Mayor, Mr. R. F. Kennedy, retiring president of the South African Museums Association, presented his report for 1947. This made it clear that South African museums suffer as much from inadequate financial support as do a large number of the museums in Britain. Mr. Kennedy stated that though applications for increases in grants for museums had been made both to the Union Government and to provincial councils, there had been little or no response. (In spite of a steady rise in costs, grants for museums in South Africa have not altered materially since 1938.) In the case of the Stateaided institutions, the Minister of the Interior had promised the formation of a special committee to study their particular needs; but no action, apparently, had actually been undertaken in this direction. Since, however, the State-aided museums now come under the Ministry of Education, there is hope that their problems will receive the attention due to them.

In his presidential address, Mr. Kennedy saw in 1948 the beginning of " $a$ considerable development in museum work in South Africa", but he reminded 
delegates that the advancement looked for would depend not so much upon Government, provincial and local taxation as upon the museums themselves. "If the museums," he said, "can show that they have a rational plan, the support of the public through their representatives will be forthcoming." In this Mr. Kennedy spoke candidly and with truth, for in most South African museums at the present time there is much room for improved and more up-todate methods of exhibition, and for the better presentation and co-ordination of the subjects with which they deal. Educational services for the general public, also, are far behind those rendered by some European and most American museums.

An important outcome of the Johannesburg conference was the formation of a special committee (to be known as the South African Museums Association Research Committee), to deal with all matters relating to research carried out by museums and allied institutions in the Union. South African museums have long been noteworthy for the amount and quality of the research they carry out in various fields; but it is now felt that there is need for the proper co-ordination of this work. This Committee, therefore, will henceforward act as the co-ordinating body. Its principal functions will be : (1) to advise Government and other authorities in matters concerning museum research; (2) to consider applications made by museums for grants, and to forward such applications with recommendations to the appropriate authority; and (3) to prepare a survey of the research already being carried out by these institutions with the object of co-ordinating this branch of museum work. Function (2), morejver, means that in future all applications from museums for research grants will automatically pass through the Research Committee for first consideration. The co-option on the same Committee of representatives of the South African Council of Scientific and Industrial Research, and of the South African Council for Educational, Sociological and Humanistic Research (constituted in 1946 by the Minister of Education to promote research in the humanistic fields), is a probability.

Another special committee which was formed at this year's meeting will press forward matters relating to increased Government support for South African museums and art galleries. It was decided, also, that a deputation from the Museums Association should ask the Transvaal Director of Education to urge the appointment of guide-lecturers for the instruction of school classes visiting Transvaal museums. The Transvaal Provincial Museum at Pretoria will send an independent deputation upon the same subject, and by now the City Council of Johannesburg will have been asked to act likewise.

The proceedings of this year's South African Museums Association conference, therefore, have made it clear that museum officials, and others interested in the work of museums, recognize the need for improvement in the Union's museum services; and from the strenuousness of discussion and the resolution which marked the whole of the meeting, there is every indication that the improvement looked for will come through equally strenuous action. One of the first necessary steps, however, will lie in an inerease of staff trained in modern museum methods and technique.

Prof. R. H. Compton was elected president of the South African Museums Association for the coming year, and Mr. E. C. Chubb was re-elected secretary.
In recognition of his long and valued service to the Association, Mr. Chubb was also elected an honorary life member.

During the conference, the Abbé Breuil, assisted by Miss Boyle, addressed the members on the Makhetha rock-shelter paintings of Basutoland and the Brandenberg rock-paintings of the Tsisab Ravine in South-west Africa; his very fine coloured drawings of these paintings decorated the walls of the conference room.

Members of the Association and visitors attended a reception in the Town Hall on the opening day of the conference, and on subsequent days visits were arranged to the University of the Witwatersrand, the Art Gallery, the South African National War Museum and the Union Astronomical Observatory.

A feature of the Johannesburg meeting was a special exhibition depicting the work, aims and needs of South African museums and art galleries. Coloured posters executed by the staff of the Africana Museum, and sets of photographs sent by individual museums and art galleries formed an attractive and informative introduction to this subject. The exhibit is available for the use of other South African museums. Its publicity value is high, and it is to be hoped that it will find its way to all museum centres in the Union. It was a pity that this exhibition did not get the press notice it deserved while it was in Johannesburg. J. R. HARDING

\section{THE IMPERIAL INSTITUTE}

$T$ HE annual report of the Imperial Institute, South Kensington, London, for 1947 shows that an unusually large number of economic inquiries and laboratory tests have been made at the Institute for Empire Governments, industrial research organisations and commercial firms in search of new sources of raw materials. In the Plant and Animal Products Department alone, 203 samples were examined and 824 inquiries handled. Three scientific papers were published by the Department recording research work on methods of pyrethrum analysis carried out in collaboration with other authorities. The consultative committees on vegetable fibres, on gums and resins, on hides, skins and tanning materials and on insecticide materials of vegetable origin all met again once during the year, and matters which received attention included manila hemp, the utilization of linseed straw, the possibility of increasing production of rosin, and the insecticidal properties of $C^{C} y m b o p o g o n$ giganteus and Neorautenania ficifolia, from Northern Rhodesia. Barataballi latex, from British Guiana, has yielded a coagulum of some promise as an ingredient of the base for chewing sweets. Trials with new insecticides as preventives against hide beetle have been completed, and a report is being prepared. The Consultative Committee on Silk has submitted to the Secretary of State for the Colonies a statement on the need for a programme of sericultural experiments in the Colonial Empire, and has also prepared for the High Commissioner for Southerm Rhodesia a report on the nature and scope of such experiments that might be undertaken in Southern Rhodesia.

Investigations reported during the year dealt with wattle bark from Jamaica, cutch from Burma, Melaleuca bracteata oil from Kenya, a possible source of methyleugenol, citrus oils from Palestine, shark liver oils from Trinidad, tung oil from Nyasaland, 